\title{
EFFECT OF FEEDING DISTILLERY DRIED GRAINS TO LACTATING COWS ON FARMS IN THE SOUTHERN DAIRY REGION OF CHILE
}

\author{
Randy Shaver ${ }^{1}$, Ricardo Ehrenfeld ${ }^{2}$, Mario Olivares ${ }^{2}$, Jaime Cuellar $^{3}$, and Francisco Inostroza ${ }^{1}$
}

\begin{abstract}
A field trial was conducted on five farms to determine the effect of feeding distillery dried grains (DDGS) on milk production in the southern dairy region of Chile. The trial was repeated on each farm during winter (July and August; primarily silage-based rations) and spring (November and December; pasture-based rations). Only for one farm could the treatments be applied concurrently by feeding different iso-nitrogenous concentrate mixes to randomly assigned cows in the milking parlor with data analyzed as a randomized complete block design. Milk yield tended ( $\mathrm{P}$ $<0.07)$ to be greater for cows fed DDGS $\left(2.0 \mathrm{~kg} \mathrm{cow}^{-1} \mathrm{~d}^{-1}\right)$ by $1.9 \mathrm{~kg} \mathrm{~d}^{-1}$ in winter and $1.8 \mathrm{~kg} \mathrm{~d}^{-1}$ in spring. In winter, milk protein yield was $(\mathrm{P}<0.02)$ greater for cows fed DDGS by $73 \mathrm{~g} \mathrm{~d}^{-1}$. Milk fat content was $(\mathrm{P}<0.01)$ lower for cows fed DDGS by $0.26 \%$-units in the spring, however, milk fat yield was unaffected by treatment. The four farms that could not apply the treatments concurrently were randomly assigned to either a control to DDGS or a DDGS to control iso-nitrogenous concentrate treatment sequence in a Crossover design with monthly feeding periods during the winter and spring. Data were analyzed as a Crossover design with farm as the experimental unit. Milk yield was $(\mathrm{P}<0.05)$ greater for farms fed DDGS $\left(2.5 \mathrm{~kg} \mathrm{cow}^{-1} \mathrm{~d}^{-1}\right)$ by $0.9 \mathrm{~kg} \mathrm{~d}^{-1}$ in winter. We conclude that DDGS was an effective dairy concentrate ingredient in the southern dairy region of Chile.
\end{abstract}

Key words: dairy cows, distillery dried grains, milk production, pasture.

\section{INTRODUCTION}

The supply of distillery dried grains with soluble (DDGS) available for livestock feeding has increased with the recent growth in USA production of ethanol from cereal grains (Mathews and McConnell, 2009). The nutrient composition (dry matter basis; NRC, 2001) of DDGS, on average, is moderate $(30 \%)$ for crude protein $(\mathrm{CP})$ relative to shelled corn (10\%) and soybean meal (SBM; $50 \%$ ), high $(51 \%)$ for rumen undegraded protein (RUP; $\%$ of $\mathrm{CP}$ ) relative to SBM (35\%), high (39\%) for neutral detergent fiber (NDF) relative to shelled corn (9\%) and corn silage (45\%), and high (10\%) for crude fat relative to shelled corn (4\%) and SBM (1.5\%). In confined feeding operations in the USA, DDGS has become a popular concentrate ingredient in dairy and beef cattle diets when priced competitively on a nutrient basis relative to other available feedstuffs (Mathews and McConnell,

${ }^{1}$ University of Wisconsin, Department of Dairy Science, Madison, Wisconsin 53706, USA. *Corresponding author (rdshaver@wisc.edu). ${ }^{2}$ Cooprinsem, Manuel Rodriguez 1040, Casilla 827, Osorno, Chile. ${ }^{3}$ US Grains Council, Bogota, Colombia.

Received: 21 May 2009.

Accepted: 08 October 2009.
2009). Schingoethe (2007) reviewed research on the use of DDGS in beef and dairy cattle diets. Relatively little research has been published with regard to the inclusion of DDGS in supplements for lactating dairy cows being fed primarily pasture for forage (Bargo et al., 2003). However, the partial replacement of corn and SBM with DDGS in concentrates supplemented to dairy cows on pasture may improve rumen function by replacing starch with digestible fiber, and energy and (or) protein status by increasing the fat and RUP concentrations in the supplements. The southern dairy region of Chile, where approximately $70 \%$ of the country's milk is produced, is largely a pasture-based dairy production system (Smith et al., 2002). We conducted a field trial on five pasture-based dairy farms near Osorno, Chile, in 2008. The objective of this trial was to determine the effect of feeding a USA-supplied corn DDGS on milk yield, composition and component yields in this pasture-region of Chile.

\section{MATERIALS AND METHODS}

The feeding trial was repeated on each of the five dairy farms during winter (July and August) and late spring 
(November and December) experimental periods to coincide with the practice of feeding forage comprised of primarily silage during the winter and pasture during the spring. Only cows that completed the 2-mo experimental period in winter or spring were included in the dataset for analysis. The numbers and composition of experimental cows on each farm are presented in Table 1.

Only for Farm E could the treatments be applied concurrently. This was done by feeding different concentrate mixes through the milking parlor concentrate feeders; one without DDGS (CONT) and one containing $40 \%$ DDGS (DIST). The average feeding rate of concentrates in the parlor was $5 \mathrm{~kg} \mathrm{cow}^{-1} \mathrm{~d}^{-1}$, and the average feeding rate of DDGS from the DIST concentrate was $2 \mathrm{~kg} \mathrm{cow}^{-1} \mathrm{~d}^{-1}$ (as fed basis). The DDGS in the DIST concentrate partially replaced, on an equivalent $\mathrm{CP}$ basis based on NRC (2001) feed table values, dry rolled shelled corn (DRSC)/SBM and dry rolled wheat (DRW)/SBM contained in the CONT concentrate during the winter and spring experimental periods, respectively.

Cows available during the winter and spring experimental periods were blocked by parity $\left(1^{\text {st }}\right.$ and $2^{\text {nd }}$ or greater lactations), randomly assigned to treatments (CONT or DIST), and fed the treatments individually for 2-mo continuously. Milk yield for individual cows was recorded daily electronically in the milking parlor, and used to calculate average daily milk yield by 2 -wk periods for each cow. Milk samples from individual cows were collected at both the morning and evening milkings on one day every 2 wk during the experimental periods and analyzed by Cooprinsem DHI Laboratory (Osorno, Chile; laboratory accreditation by Quality Advantage ISO 17025:2005 [http://www.qualityadvantage.com/

Table 1. The number, percentage first-lactation, and days in milk data for cows that completed the 2-month winter and spring experimental periods on each farm.

\begin{tabular}{llcc}
\hline Farm & n & $\begin{array}{c}\text { First-lactation } \\
\text { cows }(\%)\end{array}$ & $\begin{array}{c}\text { Days in milk at } \\
\text { trial initiation }\end{array}$ \\
\hline
\end{tabular}

\section{Winter}

\begin{tabular}{lccc} 
A & 231 & 33 & $148 \pm 97$ \\
B & 199 & 31 & $121 \pm 103$ \\
C & 100 & 33 & $128 \pm 79$ \\
D & 201 & 26 & $173 \pm 124$ \\
E & 130 & 30 & $129 \pm 78$ \\
Spring & & & \\
A & 256 & 28 & $160 \pm 103$ \\
B & 137 & 24 & $89 \pm 55$ \\
C & 82 & 0 & $105 \pm 55$ \\
D & 169 & 24 & $146 \pm 116$ \\
E & 170 & 28 & $159 \pm 218$ \\
\hline
\end{tabular}

iso_17025.htm]) for fat, protein, and urea contents and somatic cell count (SCC) using near infrared analysis (Foss Electric, Hillerød, Denmark). Individual cow milk yield, composition and component yields for the 2-wk test periods were used in the statistical analysis. Data were analyzed as a randomized complete block design with a cow as the experimental unit using the PROC MIXED procedure of SAS (SAS Institute, 2004). The model included parity, treatment, and the parity by treatment interaction as fixed effects, and cow within treatment as a random effect. Degrees of freedom were calculated using the Kenward-Roger option (SAS Institute, 2004). The least squares mean statement was used to determine treatment means. Statistical significance and trends were considered at $\mathrm{P}>0.05$ and $\mathrm{P}>0.06$ to $\mathrm{P}<0.15$, respectively.

The other four farms could not apply the treatments concurrently. These farms (A-D) were randomly assigned to either a CONT to DIST or a DIST to CONT treatment sequence in a crossover design with monthly feeding periods during the winter and spring experimental periods. The CONT or DIST concentrates were fed to the whole herd on each of the four farms in the bunk mixed with silage prior to milking according to their respective treatment sequence during the winter and spring experimental periods. The average feeding rate of DDGS from the DIST concentrate was $2.5 \mathrm{~kg} \mathrm{cow}^{-1} \mathrm{~d}^{-1}$ (as fed basis). The DDGS in the DIST concentrate partially replaced, on an equivalent CP basis based on NRC (2001) feed table values, DRSC and DRW/SBM (Farm A), highmoisture corn (HMC)/canola meal (CNM; Farm B), DRSC/peanut meal (Farm C), and DRSC/SBM (Farm D) contained in the CONT concentrates during the winter experimental period. During the spring experimental period, the DDGS in the DIST concentrate partially replaced, on an equivalent $\mathrm{CP}$ basis, DRW/SBM (Farms $\mathrm{A}$ and D), HMC/CNM (Farm B), and DRSC/wheat Middlings (Farm C). Milk yield for individual cows was recorded daily electronically in the milking parlor (Farms A and D) or on $1 \mathrm{~d}$ every 2-wk by Cooprinsem DHI using meters in the milking parlor (Farms B and C) during the experimental periods. Milk samples from individual cows were collected at both the morning and evening milkings on $1 \mathrm{~d}$ every 2 -wk during the experimental periods by Cooprinsem DHI for milk composition analysis as described previously. Individual cow level milk yield, composition and component yield data were used to calculate experimental farm level data for each 2-wk period for statistical analysis. Data were analyzed as a crossover design with farm as the experimental unit (St. Pierre, 2001) using the PROC MIXED procedure of SAS (SAS Institute, 2004). The model included period, sequence, and treatment as fixed effects, and farm as a 
random effect. Degrees of freedom were calculated using the Kenward-Roger option. The least squares mean statement was used to determine treatment means. Statistical significance and trends were considered at $\mathrm{P}>$ 0.05 and $\mathrm{P}>0.06$ to $\mathrm{P}<0.15$, respectively.

Samples of ryegrass (mixture of Lolium multiflorum Lam., L. perenne L. and L. xhybridum Hausskn.) pasture and silage were collected every 2 -wk from each farm during both winter and spring experimental periods. The ryegrass pastures were sampled by Cooprinsem personnel as described by Rayburn (2003). Ryegrass silage samples were obtained, when silage was being fed, by Cooprinsem personnel as described Undersander et al. (2005). The DDGS fed during the winter and spring experimental periods on each farm were sampled by Cooprinsem staff. Samples were analyzed using wet chemistry procedures (NFTA, 2009) for nutrient composition by AgSource Soil \& Forage Lab (Bonduel, Wisconsin, USA).

\section{RESULTS AND DISCUSSION}

The nutrient composition of ryegrass pasture and silage samples is presented in Table 2. Pasture samples were of high quality relative to NRC (2001), and higher in quality than ryegrass silage samples. Lower quality for ryegrass silage than pasture samples was likely related to advanced maturity for silage harvest and nutrient losses during silage fermentation. Lower $\mathrm{CP}$ and higher NDF contents for late spring than winter pasture samples were likely related to the dilution effect of greater yield during the spring on the concentration of these nutrients. Few silage samples were analyzed for the spring experimental

Table 2. Nutrient composition of ryegrass pasture and silage samples during the winter and spring experimental periods.

\begin{tabular}{|c|c|c|}
\hline \multirow[b]{3}{*}{ Nutrient } & \multicolumn{2}{|c|}{ Ryegrass } \\
\hline & Pasture & Silage $^{1}$ \\
\hline & \multicolumn{2}{|c|}{$\% \mathrm{DM}$} \\
\hline Winter & $\mathrm{n}=19$ & $\mathrm{n}=21$ \\
\hline Crude protein & $29.2 \pm 4.6$ & $15.0 \pm 4.1$ \\
\hline Neutral detergent fiber & $41.8 \pm 6.3$ & $46.6 \pm 5.7$ \\
\hline Acid detergent fiber & $27.2 \pm 4.8$ & $29.8 \pm 3.3$ \\
\hline Total digestible nutrients ${ }^{2}$ & $67.7 \pm 7.1$ & $65.7 \pm 5.0$ \\
\hline Spring & $\mathrm{n}=38$ & $\mathrm{n}=2$ \\
\hline Crude protein & $22.7 \pm 5.3$ & $13.0 \pm 1.1$ \\
\hline Neutral detergent fiber & $44.0 \pm 5.2$ & $49.8 \pm 9.9$ \\
\hline Acid detergent fiber & $27.2 \pm 2.9$ & $29.8 \pm 6.1$ \\
\hline Total digestible nutrients ${ }^{2}$ & $67.7 \pm 4.3$ & $65.7 \pm 9.1$ \\
\hline
\end{tabular}

${ }^{1} \mathrm{DM}=29.4 \pm 6.3$ in Winter and $31.0 \pm 14.8$ in Spring.

${ }^{2}$ Calculated as 88.9 - (0.779* ADF \%); Rohweder et al. (1978). period, because pasture was the primary or sole forage fed. The nutrient composition of the DDGS samples is presented in Table 3. The average CP content of DDGS was similar to NRC (2001), while the average contents of NDF and ether extract were 9\%-units lower and 2\%-units greater, respectively, than reported by NRC (2001). The low variation in nutrient composition observed among the samples was expected, because the USA-supplied corn DDGS used for the experiment was from one supplier. Coefficients of variation (standard deviation divided by mean) across many DDGS sources were 10\%, 21\% and $40 \%$ for CP, NDF and ether extract, respectively (NRC, 2001).

Lactation performance results for Farm E (Table 4) were analyzed as randomized complete block design with cow as the experimental unit. Parity $\mathrm{x}$ treatment interactions were not detected $(\mathrm{P}>0.15)$. Milk yield tended $(\mathrm{P}<0.07)$ to be greater for cows fed DIST by $1.9 \mathrm{~kg} \mathrm{~d}^{-1}$ in winter and $1.8 \mathrm{~kg} \mathrm{~d}^{-1}$ in late spring. The trend for an increase in milk yield for cows fed DIST may have been related to the high RUP and fat concentrations for DDGS (NRC, 2001). Responses to RUP in pasture-fed cows were equivocal in the review of Bargo et al. (2003), who did not find trials with DDGS. Milk composition was unaffected by treatment in the winter, however, milk fat yield tended $(\mathrm{P}<$ $0.11)$ to be greater and milk protein yield was $(\mathrm{P}<$ 0.02 ) greater for cows fed DIST by 75 and $73 \mathrm{~g} \mathrm{~d}^{-1}$, respectively, in relationship to the trend for greater milk yield observed for DIST. Milk fat content was $(\mathrm{P}<0.01)$ lower for cows fed DIST by $0.26 \%$-units in the spring, however, milk fat yield was unaffected by treatment. In agreement with our findings, reduced milk fat content with no change in yield of fat in response to feeding DDGS was reported by Leonardi et al. (2005). High content of unsaturated fatty acids in DDGS (Leonardi et al., 2005) is the probable cause of depression in milk fat content (Bauman and Griinari, 2000) observed in response to feeding DDGS. This

Table 3. Nutrient composition of the distillery dried grains fed throughout the experiment ${ }^{1}$.

\begin{tabular}{ll}
\hline Dry matter (DM), \% as fed & $88.3 \pm 2.1$ \\
Crude protein, \% DM & $30.8 \pm 1.2$ \\
Neutral detergent fiber, \% DM & $29.5 \pm 2.1$ \\
Acid detergent fiber, \% DM & $11.0 \pm 1.7$ \\
Ether extract, \% DM & $12.1 \pm 0.6$ \\
Metabolizable energy, Mcal kg-1 DM $^{2}$ & $3.32 \pm 0.23$ \\
Calcium, \% DM & $0.05 \pm 0.01$ \\
Phosphorus, \% DM & $0.86 \pm 0.08$
\end{tabular}

${ }^{1} \mathrm{n}=10$

${ }^{2}$ Calculated from nutrient composition using NRC (2001) equations. 
Table 4. Treatment effects on lactation performance least squares means for Farm $\mathbf{E}$ where data were analyzed as a randomized complete block design with cows as the experimental unit.

\begin{tabular}{lcccc}
\hline Item & Control & Distillery dried grains & SEM & $(\boldsymbol{P}<)$ \\
\hline Winter & & & & \\
Milk yield, kg d & -1 & 31.0 & 0.8 & 0.07 \\
Fat, \% & 29.1 & 4.09 & 0.07 & NS2 \\
Fat, g d $^{-1}$ & 4.17 & 1287 & 34 & 0.11 \\
Protein, \% & 1212 & 3.38 & 0.05 & NS \\
Protein, g d $^{-1}$ & 3.42 & 1062 & 24 & 0.02 \\
Urea, mg L $^{-1}$ & 989 & 619 & 10 & NS \\
SCC3, x 1000 $_{\text {Spring }}$ & 612 & 157 & 36 & NS \\
Milk yield, kg d & 132 & & & \\
Fat, $\%$ & & 34.7 & 1.0 & 0.07 \\
Fat, g d $^{-1}$ & 32.9 & 3.42 & 0.08 & 0.01 \\
Protein, $\%$ & 3.68 & 1180 & 35 & NS \\
Protein, g d $^{-1}$ & 1193 & 3.45 & 0.04 & NS \\
Urea, mg L $^{-1}$ & 3.51 & 1196 & 29 & 0.09 \\
SCC, x 1000 & 1146 & 357 & 9 & NS \\
\hline
\end{tabular}

SEM: Standard error of the mean; NS: Non significant; SCC: Somatic cell count.

response may be more pronounced during the spring when pasture comprises most of the dietary forage and the content of unsaturated fatty acids in pasture is the highest (Chilliard et al., 2000). Other milk composition measurements (protein, urea and SCC) were unaffected by treatment in the spring. Milk protein yield tended $(\mathrm{P}<0.09)$ to be greater for cows fed DIST by $50 \mathrm{~g} \mathrm{~d}^{-1}$ during the spring in relationship to the greater milk yield observed for DIST.

Lactation performance results for Farms A-D (Table 5) were analyzed using a mixed models procedure with period, sequence and treatment as fixed effects and farm within sequence as a random effect. Milk yield in winter was $(\mathrm{P}<0.05)$ greater for farms fed DIST by $0.9 \mathrm{~kg} \mathrm{~d}^{-1}$. Milk fat $(\mathrm{P}<0.07)$ and protein $(\mathrm{P}<0.06)$ contents tended to be lower for farms fed DIST in Winter, however, fat and protein contents for these farms when fed DIST ( $3.99 \%$ and $3.37 \%$, respectively) were not indicative of a depression in milk composition (Pulido et al., 2009), and yields of fat and protein were unaffected by treatment. Milk urea and SCC were unaffected by treatment in winter. The feeding of DIST during the late spring did not affect milk yield, composition or component yields on these farms. The lack of milk yield response to DDGS in the spring for the 4-farm combined analysis may have been related to higher quality forage from pasture in the spring more closely meeting the nutrient requirements for milk production. We have no explanation for why this may have occurred, however, for Farms A-D and not Farm E. But, it is possible that differences in pasture management among the farms may have affected the milk yield response observed during the spring feeding period. The consistent lack of treatment effects on milk urea and SCC across all farms and both experimental periods indicates that feeding DDGS was not adverse to these cow health related measurements.

\section{CONCLUSIONS}

Distillery dried grains (2.0 to $2.5 \mathrm{~kg} \mathrm{cow}^{-1} \mathrm{~d}^{-1}$ ) were an effective dairy concentrate ingredient in the pasture region of southern Chile under the conditions of this study. Longer-term lactation trials and studies with higher inclusion amounts for distillery dried grains are warranted. Potential combined effects of unsaturated fatty acids from distillers dried grains and spring pasture on reduced milk fat content merits further study.

\section{ACKNOWLEDGEMENTS}

We appreciate the cooperation of the five Chilean dairy farmers, the efforts of the Cooprinsem staff, and the partial funding for the study provided by the U.S. Grains Council. 
Table 5. Treatment effects on lactation performance least squares means for Farms A-D where data were analyzed using a mixed models procedure with period, sequence and treatment as fixed effects and farm within sequence as a random effect.

\begin{tabular}{|c|c|c|c|c|}
\hline Item & Control & Distillery dried grains & SEM & $(\boldsymbol{P}<)$ \\
\hline \multicolumn{5}{|l|}{ Winter } \\
\hline Milk yield, $\mathrm{kg} \mathrm{d}^{-1}$ & 27.8 & 28.7 & 0.2 & 0.05 \\
\hline Fat, $\%$ & 4.10 & 3.99 & 0.03 & 0.07 \\
\hline Fat, $\mathrm{g} \mathrm{d}^{-1}$ & 1115 & 1117 & 2 & NS2 \\
\hline Protein, \% & 3.41 & 3.37 & 0.01 & 0.06 \\
\hline Protein, $\mathrm{g} \mathrm{d}^{-1}$ & 927 & 943 & 11 & NS \\
\hline Urea, $\mathrm{mg} \mathrm{L}^{-1}$ & 178 & 180 & 8 & NS \\
\hline $\mathrm{SCC} 3, \times 1000$ & 412 & 430 & 22 & NS \\
\hline \multicolumn{5}{|l|}{ Spring } \\
\hline Milk yield, $\mathrm{kg} \mathrm{d}^{-1}$ & 32.9 & 32.5 & 0.8 & NS \\
\hline Fat, $\%$ & 3.52 & 3.48 & 0.09 & NS \\
\hline Fat, $\mathrm{g} \mathrm{d}^{-1}$ & 1153 & 1130 & 59 & NS \\
\hline Protein, \% & 3.36 & 3.33 & 0.02 & NS \\
\hline Protein, $\mathrm{g} \mathrm{d}^{-1}$ & 1104 & 1077 & 27 & NS \\
\hline Urea, $\mathrm{mg} \mathrm{L}^{-1}$ & 347 & 320 & 30 & NS \\
\hline SCC, x 1000 & 241 & 234 & 25 & NS \\
\hline
\end{tabular}

SEM: Standard error of the mean; NS: Non significant; SCC: Somatic cell count.

\section{RESUMEN}

Efecto de la alimentación con granos secos de destilería en vacas en lactancia de la región lechera del sur de Chile. Para medir el efecto de la suplementación con granos secos de destilería (DDGS) en producción de leche se realizó un ensayo en cinco lecherías del sur de Chile. Se tuvo una fase invernal (julio-agosto, basada en ensilajes), una primaveral (noviembre-diciembre, basada en praderas). En una lechería se aplicó un tratamiento simultáneo, alimentando las vacas durante la ordeña con diferentes mezclas de concentrados isoproteicos asignados aleatoriamente. Se analizaron resultados utilizando un diseño de bloques completos al azar, donde las vacas fueron la unidad experimental. La producción de leche tendió a ser mayor $1,9 \mathrm{~kg} \mathrm{~d}^{-1}$ en invierno, $1,8 \mathrm{~kg} \mathrm{~d}^{-1}$ en primavera $(\mathrm{P}<0,07)$, en vacas alimentadas con DDGS $\left(2,0 \mathrm{~kg} \mathrm{vaca}^{-1} \mathrm{~d}^{-1}\right)$. En invierno, el porcentaje de proteína en las vacas suplementadas con DDGS fue mayor en $73 \mathrm{~g} \mathrm{~d}^{-1}$ $(\mathrm{P}<0,02)$. El contenido de grasa fue $(\mathrm{P}<0,01)$ menor en 0,26 unidades porcentuales en las vacas alimentadas con DDGS durante la primavera, sin embargo, la producción total de grasa no se afectó por el tratamiento. En las lecherías que no se utilizó el tratamiento simultáneo, las vacas se asignaron al azar en invierno y primavera, a una secuencia de 1 mes de alimentación con concentrados isoproteicos Control-DDGS o DDGS-Control. Los datos fueron analizados con un diseño cruzado en el cual la lechería fue la unidad experimental. En invierno, con la suplementación con DDGS $\left(2,5 \mathrm{~kg} \mathrm{vaca}^{-1} \mathrm{~d}^{-1}\right)$ la producción de leche fue $(\mathrm{P}<0,05)$ mayor en $0,9 \mathrm{~kg} \mathrm{~d}^{-1}$. Los DDGS fueron alimentos efectivos en concentrados utilizados en vacas lecheras.

Palabras clave: vacas lecheras, granos secos de destilería, producción de leche, pastoreo.

\section{LITERATURE CITED}

Bargo, F., L.D. Muller, E.S. Kolver, and J.E. Delahoy. 2003. Invited review: Production and digestion of supplemented dairy cows on pasture. J. Dairy Sci. 86:1-42.

Bauman, D.E., and J.M. Griinari. 2000. Regulation and nutritional manipulation of milk fat: Low-fat milk syndrome. Livest. Prod. Sci. 70:15-29.

Chilliard, Y., A. Ferlay, and M. Doreau. 2000. Effect of different types of forages, animal fat or marine oils in cow's diet on milk fat secretion and composition, especially conjugated linoleic acid (CLA) and polyunsaturated fatty acids. Livest. Prod. Sci. 70:3148.

Leonardi, C., S. Bertics, and L.E. Armentano. 2005. Effect of increasing corn oil from distillers grains or corn oil on lactation performance. J. Dairy Sci. 88:2820-2827. 
Mathews, Jr., K.H., and M.M. McConnell. 2009. Ethanol co-product use in U.S. cattle feeding: Lessons learned and considerations. Report from the Econ. Res. Serv. U.S. Dept. of Agric. FDS-09D-01. Available at http://www.ers.usda. gov/Publications/FDS/2009/04Apr/FDS09D01/ FDS09D01.pdf (accessed 11 May 2009).

NFTA. 2009. Forage analysis procedures. National Forage Testing Association (NFTA), Omaha, Nebraska, USA. Available at http://www.foragetesting.org/index. php?page=lab_procedures (accessed 12 May 2009).

NRC. 2001. Nutrient requirements of dairy cattle. $7^{\text {th }}$ rev. ed. National Research Council. Nat. Acad. Press, Washington, DC., USA.

Pulido, R.G., R. Muñoz, P. Lemarie, F. Wittwer, P. Orellana, and G.C. Waghorn. 2009. Impact of increasing grain feeding frequency on production of dairy cows grazing pasture. Livest. Sci. 125:109-114.

Rayburn,E. 2003. Sampling pastures for nutritive analysis. Forage management. West Virginia Univ. Ext. Serv. Available at http://www.wvu.edu/ Agexten/forglvst/ samplpass.pdf (accessed 14 October 2009).
Rohweder, D.A., R.F. Barnes, and N.A. Jorgensen. 1978. Proposed hay grading standards based on laboratory analysis for evaluating quality. J. Anim. Sci. 47:747759.

SAS Institute. 2004. SAS/STAT 9.1 User's guide. Version 9.1. SAS Institute, Cary, North Carolina, USA.

Schingoethe, D.J. 2007. Strategies, benefits, and challenges of feeding ethanol byproducts to dairy and beef cattle. Proc. $18^{\text {th }}$ Florida Ruminant Nutrition Symposium, Gainesville, Florida, USA.

Smith, R., V. Moreira, and L. Latrille. 2002. Characterization of dairy productive systems in the Tenth Region of Chile using multivariate analysis. Agric. Tec. (Chile) 62:375-395.

St. Pierre, N.R. 2001. Invited review: Integrating quantitative findings from multiple studies using mixed model methodology. J. Dairy Sci. 84:741.

Undersander, D., R. Shaver, J. Linn, P. Hoffman, and P. Peterson. 2005. Sampling hay, silage, and total mixed rations for analysis. Univ. of Wisconsin Ext. A2309. Available at http://learningstore.uwex.edu/pdf/A2309. pdf (accessed 12 May 2009). 